\title{
Human Capital and Smart Growth in the EU Countries in 2010-2014
}

\author{
Iwona SKRODZKA \\ ${ }^{1}$ University of Bialystok, Białystok, Poland \\ i.skrodzka@uwb.edu.pl
}

\begin{abstract}
The purpose of the paper is to analyze the role of human capital in the processes of smart growth in EU countries in 2010-2014. Smart growth it is growth based on two driving forces: knowledge and innovation. The importance of human capital in the processes of growth and economic development has been broadly discussed in the literature, but the issue of smart growth and its factors, in particular human capital is a relatively new one. The study uses a soft modelling method, which enables to investigate relationships between unobserved variables (e.g. human capital, smart growth). Moreover this method makes it possible to estimate a synthetic measures of human capital and the level of smart growth as well as the to order and classify of the EU countries into typological groups.
\end{abstract}

Keywords: Smart Growth, Human Capital, Soft Modelling.

\section{Introduction}

Smart growth it is growth based on two driving forces: knowledge and innovation [6, pp. 8]. The issue of smart growth is a relatively new one, yet it has already been discussed by a few authors $[1,13,14,21]$. Nevertheless, studies on this topic are scarce. Their authors unanimously agree that there is a need for detailed theoretical and empirical research. The pillars of smart growth, i.e. knowledge and innovation, have been broadly discussed in the literature. According to the definition coined by the OECD and the World Bank Institute, knowledge-base economy (KBE) is an economy where knowledge is created, acquired, transmitted and used effectively by enterprises, organizations, individuals and communities [15, pp. 3]. It is also assumed that KBE consists of four pillars [16, pp. 217]:

- human capital, in whom some knowledge is stored,

- innovation system with entrepreneurship, more focused on businesses but also on cooperation with science, which also creates new knowledge,

- teleinformation technologies, which facilitate knowledge exchange, also abroad,

- institutional and legal environment, which creates conditions for the development of the above-mentioned areas. 
One of those four pillars is human capital. Human capital can be defined as a embodied in inhabitants stock of unobserved characteristics. It is increased through investment and it is an important factor of economic development [19, pp. 28]. The importance of human capital in the processes of growth and economic development has been broadly discussed in the literature $[2,11,12,18]$. Human capital as a factor of economic growth occurs both in theoretical and empirical models. Hence, it seems reasonable to formulate a hypothesis that human capital influences positively on the level of smart growth in the EU countries.

The purpose of the paper is to analyze the relationship between human capital and the level of smart growth in EU countries in 2010-2014. This research uses the method of soft modelling which allows to examine links between variables which are not directly observable (latent variables).

\section{Research Method}

The soft modelling method (in the literature also referred to as PLS Path Modeling) was developed by $\mathrm{H}$. Wold $[22,23]$. The method makes it possible to investigate relations between variables which are not directly observable (latent variables). The values of such variables cannot be measured in a straightforward manner because of the lack of a widely accepted definition or a uniform method of their measurement. Examples of use of the soft modeling method in economic research (technology transfer, the level of innovation, human capital, knowledge-based economy) can be found in the following papers $[5,19,20]$.

The soft model consists of two sub-models: an internal one (structural model) and an external one (measurement model). The internal sub-model depicts the relationships between the latent variables on the basis of the assumed theoretical description. The external sub-model defines latent variables by means of observable variables (indicators). Indicators allow for direct observation of latent variables and are selected according to the assumed theory or the intuition of the researcher. A latent variable can either be defined (with the use of indicators) inductively: the approach is based on the assumption that the indicators make up latent variables (formative indicators), or deductively: when it is assumed that indicators reflect the respective theoretical notions (reflective indicators). Under the deductive approach, the latent variable, as a theoretical notion, is a point of departure for a search of empirical data (the variable is primary to a given indicator). In the inductive approach, it is the indicators that are primary to the latent variable which they comprise. Both the approaches use latent variables that are estimated as the weighted sums of their indicators. However, depending on the definition, indicators should be characterized by different statistical properties (no correlation in the case of inductive definition and high correlation in the deductive one) [17, pp. 33-37].

The estimation of the parameters of the soft model is performed by means of the partial least squares method - PLS method (more in $[8,10]$ ). The quality of the model is assessed with the use of determination coefficients $\left(\mathrm{R}^{2}\right)$, established for each equation. The significance of the parameters is checked by means of the standard 
deviations calculated with the Tukey's range test (" $2 \mathrm{~s}$ " rule: a parameter significantly differs from zero if double standard deviation does not exceed the value of the estimator of this parameter) [9]. Besides, in the case of the external submodel, the estimators of factor loadings can be treated as the degree in which the indicators match the latent variable that they define. The prognostic property of model can be evaluated by means of the Stone-Geisser test [3], which measures the accuracy of the forecast obtained as a result of the model's application as compared with a trivial forecast. The test statistics take values from the range $<-\infty, 1>$. In the ideal model, the value of the test equals 1 (the forecasts are perfectly accurate in comparison with trivial forecasts). When the value of the test equals zero, the quality of the model's forecast and the trivial forecast tend to be virtually identical. Negative values indicate a low quality of the model (its weak predictive usefulness compared with a trivial forecast).

Using the partial least squares method, it is possible to obtain the estimated values of latent variables, which can be regarded as the values of synthetic measures. They can be employed for linear ordering of the examined objects. These values depend not only on the external relationships, but also on the relationships between the latent variables which are assumed for the internal model. This means that the cognitive process hinges not merely on the definition of a given notion, but also on its theoretical description [17, pp. 37-38].

\section{Specification of the Soft Model}

The model used in the present paper to reach its aim of determining the influence of human capital on the level of smart growth contains the following equation

$$
S G_{\mathrm{t}}=\alpha_{1} H C_{\mathrm{t}}+\alpha_{0}+v,
$$

where

$S G$ - the level of smart growth,

$H C$ - human capital,

$\alpha_{0}, \alpha_{1}-$ structural parameters of the model,

$v$ - random parameter,

$\mathrm{t}-$ year 2010 or 2014

The latent variables $H C$ and $S G$ are defined by means of observable variables on the basis of the deductive approach, i.e. the latent variable, as a theoretical concept, serves as a starting point to identify empirical data. The statistical data come from the Eurostat and World Bank databases. The selection of the research period was determined by the availability of statistical data. The indicators for the model were selected based on criteria of substantive and statistical nature. The initial set of indicators was created on the basis of following methodology: Knowledge Assessment Methodology (KAM, see in [4]) and European Innovation Scoreboard Methodology (EIS, see in [7]). From the statistical point of view, the following considerations were taken into account: variability of indicator values (coefficient of variation above 10\%) and analysis of the quality of the estimated model (ex post 
analysis). The lacking data were supplemented through naive forecasting, which involves replacing the deficient figure with another, adjacent one.

Tables 1 and 2 contain a summary of the indicators after substantive and statistical verification. Three indicators qualified for the model are destimulants of $H C$ latent variable, i.e. the higher the value of an indicator, the lower the level of the latent variable. The rest of indicators are stimulants of $H C$ latent variable, i.e. the higher the value of an indicator, the higher the level of the latent variable. All the indicators qualified for the model are stimulants of $S G$ latent variable.

Table 1. Indicators of $H C$ latent variable qualified for the model

\begin{tabular}{|c|c|c|c|}
\hline $\begin{array}{l}\text { Symbol of } \\
\text { indicator }\end{array}$ & Description of indicator & Source & Type \\
\hline HC01 & $\begin{array}{l}\text { Percentage of population aged } 15-64 \text { having } \\
\text { completed tertiary education }(\%) \text {. }\end{array}$ & Eurostat & Stimulant \\
\hline $\mathrm{HCO} 2$ & $\begin{array}{l}\text { Percentage of population aged } 25-64 \\
\text { participating in education and training }(\%) \text {. }\end{array}$ & Eurostat & Stimulant \\
\hline $\mathrm{HCO3}$ & $\begin{array}{l}\text { Percentage of employees aged } 15-64 \text { having } \\
\text { completed tertiary education }(\%) \text {. }\end{array}$ & Eurostat & Stimulant \\
\hline $\mathrm{HCO} 4$ & $\begin{array}{l}\text { Percentage of employees aged } 25-64 \\
\text { participating in education and training }(\%) \text {. }\end{array}$ & Eurostat & Stimulant \\
\hline $\mathrm{HCO5}$ & $\begin{array}{l}\text { Early leavers from education and training, } \\
\text { percentage of population aged } 18-24(\%) \text {. }\end{array}$ & Eurostat & Destimulant \\
\hline HC06 & $\begin{array}{l}\text { Graduates in tertiary education per } 1000 \text { of } \\
\text { population aged 20-29 (person). }\end{array}$ & Eurostat & Stimulant \\
\hline $\mathrm{HCO7}$ & $\begin{array}{l}\text { Graduates at doctoral level per } 1000 \text { of } \\
\text { population aged 25-34 (person). }\end{array}$ & Eurostat & Stimulant \\
\hline HCO8 & $\begin{array}{l}\text { Percentage of population declaring their health } \\
\text { status as very good and good }(\%) .\end{array}$ & Eurostat & Stimulant \\
\hline HCO9 & $\begin{array}{l}\text { Percentage of population declaring their health } \\
\text { status as bad and very bad }(\%) .\end{array}$ & Eurostat & Destimulant \\
\hline$H C 10$ & $\begin{array}{l}\text { Average years of schooling of population aged } \\
25+\text { (years). }\end{array}$ & World Bank & Stimulant \\
\hline HC11 & Infant mortality rate (person). & World Bank & Destimulant \\
\hline
\end{tabular}


Table 2. Indicators of $S G$ latent variable qualified for the model

\begin{tabular}{|c|c|c|c|}
\hline $\begin{array}{l}\text { Symbol of } \\
\text { indicator }\end{array}$ & Description of indicator & Source & Type \\
\hline KNOW01 & Researchers as percentage of total employment (\%). & Eurostat & Stimulant \\
\hline KNOW02 & $\begin{array}{l}\text { Researchers in business enterprise sector as } \\
\text { percentage of total employment }(\%) \text {. }\end{array}$ & Eurostat & Stimulant \\
\hline KNOW03 & $\begin{array}{l}\text { Graduates in tertiary education, in science, } \\
\text { mathematics, computing, engineering, } \\
\text { manufacturing, construction per } 1000 \text { of population } \\
\text { aged } 20-29 \text { (person). }\end{array}$ & Eurostat & Stimulant \\
\hline KNOW04 & $\begin{array}{l}\text { Graduates at doctoral level, in science, mathematics, } \\
\text { computing, engineering, manufacturing, construction } \\
\text { per } 1000 \text { of population aged } 25-34 \text { (person). }\end{array}$ & Eurostat & Stimulant \\
\hline KNOW05 & $\begin{array}{l}\text { Scientific and technical journal articles per } 1 \text { million } \\
\text { inhabitants (number). }\end{array}$ & World Bank & Stimulant \\
\hline INNO01 & $\begin{array}{l}\text { Patent applications to the EPO per } 1 \text { million } \\
\text { inhabitants (number). }\end{array}$ & Eurostat & Stimulant \\
\hline INNO02 & $\begin{array}{l}\text { Exports of high technology products as a share of } \\
\text { total exports }(\%) \text {. }\end{array}$ & Eurostat & Stimulant \\
\hline INNO03 & $\begin{array}{l}\text { Product and/or process innovative enterprises as } \\
\text { percentage of total }(\%) \text {. }\end{array}$ & Eurostat & Stimulant \\
\hline INNO04 & $\begin{array}{l}\text { Organization and/or marketing innovative } \\
\text { enterprises as percentage of total }(\%) .\end{array}$ & Eurostat & Stimulant \\
\hline INNO05 & $\begin{array}{l}\text { Total turnover of innovative enterprises as } \\
\text { percentage of GDP }(\%) \text {. }\end{array}$ & Eurostat & Stimulant \\
\hline INNO06 & $\begin{array}{l}\text { Charges for the use of intellectual property (receipts) } \\
\text { as percentage of GDP }(\%) \text {. }\end{array}$ & World Bank & Stimulant \\
\hline
\end{tabular}

A diagram of the soft model, depicting both the internal and external relationships is shown in Figure 1. The solid line applies to the relationships in the internal model, while the dotted line - to those in the external model. 


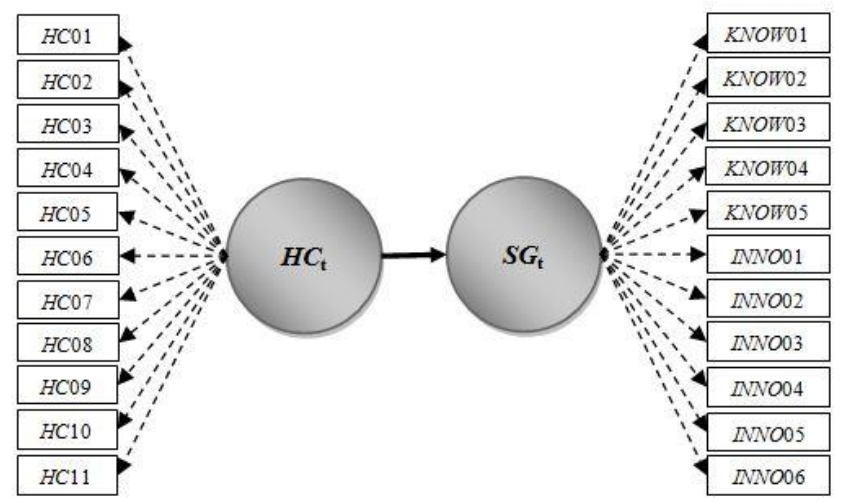

Fig. 1. Diagram of internal and external relationships in soft model

The model was estimated by means of the PLS method, which involves simultaneous estimation of the external model parameters (weights and factor loadings) and the internal model parameters (structural parameters). The estimation was conducted using the PLS software. The software was developed by J. Rogowski, $\mathrm{PhD}$, professor at the Department of Economics and Management at University of Bialystok, and is available free of charge.

\section{$4 \quad$ Estimation Results}

Within the external model, the weights and factor loadings were estimated. A weight represents the relative share of a given indicator's value in the estimated value of a latent variable. A factor loading is a coefficient of the correlation between an indicator and the estimated values of a latent variable, thus it reveals the degree and direction in which the variability of a given indicator reflects the variability of the latent variable. Ordering of indicators according to their weights is done when the latent variable is defined inductively. Under the deductive approach, which is used in the present study, it is the factor loadings that are interpreted. The following interpretation of factor loading $\xi$ was assumed:

$|\xi|<0.2$ - no correlation,

$0.2 \leq|\xi|<0.4$ - weak correlation,

$0.4 \leq|\xi|<0.7$ - moderate correlation,

$0.7 \leq|\xi|<0.9$ - strong correlation,

$|\xi| \geq 0.9$ - very strong correlation.

Table 3 presents the estimates of factor loadings and standard deviations. The results are as expected - the estimates for stimulants are positive and for destimulants - negative. Some parameters are not statistically significant according to the " $2 \mathrm{~s}$ " rule. Indicators: INNO01, INNO02 and INNO04 are not statistically significant in the 2010 model. However, they were not removed from the model due to its importance 
in reflecting innovative processes. The substantive criterion was more important than the statistical one. The 2014 model results also had an impact on this decision.

Table 3. Estimations of external relationships of soft model

\begin{tabular}{|c|c|c|c|c|}
\hline \multirow{2}{*}{$\begin{array}{l}\text { Symbol of } \\
\text { indicator }\end{array}$} & \multicolumn{2}{|c|}{2010} & \multicolumn{2}{|c|}{2014} \\
\hline & Factor loading & $\begin{array}{l}\text { Standard } \\
\text { deviation }\end{array}$ & Factor loading & $\begin{array}{l}\text { Standard } \\
\text { deviation }\end{array}$ \\
\hline HC01 & 0.7087 & 0.0228 & 0.6757 & 0.0173 \\
\hline $\mathrm{HCO} 2$ & 0.9095 & 0.0106 & 0.9020 & 0.0084 \\
\hline $\mathrm{HCO3}$ & 0.5251 & 0.0261 & 0.5101 & 0.0199 \\
\hline $\mathrm{HCO} 4$ & 0.9058 & 0.0106 & 0.8913 & 0.0084 \\
\hline HCO5 & -0.1821 & 0.0269 & -0.2512 & 0.0319 \\
\hline HC06 & 0.1564 & 0.0165 & 0.2939 & 0.0077 \\
\hline $\mathrm{HCO7}$ & 0.5770 & 0.0282 & 0.6265 & 0.0188 \\
\hline HC08 & 0.6019 & 0.0307 & 0.5490 & 0.0285 \\
\hline HCO9 & -0.6202 & 0.0309 & -0.6398 & 0.0283 \\
\hline$H C 10$ & 0.3168 & 0.0180 & 0.2482 & 0.0156 \\
\hline$H C 11$ & -0.4306 & 0.0208 & -0.4808 & 0.0214 \\
\hline KNOW01 & 0.8854 & 0.0425 & 0.9397 & 0.0432 \\
\hline KNOW02 & 0.9018 & 0.0366 & 0.9521 & 0.0213 \\
\hline KNOW03 & 0.2958 & 0.0883 & 0.3347 & 0.0902 \\
\hline KNOW04 & 0.7407 & 0.0646 & 0.7897 & 0.0604 \\
\hline KNOW05 & 0.9110 & 0.0345 & 0.8698 & 0.0443 \\
\hline INNO01 & 0.0711 & 0.1146 & 0.8764 & 0.0350 \\
\hline INNO02 & 0.1568 & 0.1187 & 0.2798 & 0.0853 \\
\hline INNO03 & 0.6579 & 0.0352 & 0.5827 & 0.0651 \\
\hline INNO04 & -0.0992 & 0.0619 & 0.3159 & 0.0345 \\
\hline INNO05 & 0.1563 & 0.0450 & 0.4178 & 0.0465 \\
\hline INNO06 & 0.3485 & 0.1022 & 0.4012 & 0.0879 \\
\hline
\end{tabular}

The indicators reflect their latent variables with varying intensity. The $H C$ latent variable is very strongly correlated with two indicators: "percentage of population aged 25-64 participating in education and training" (HCO2) and "percentage of employees aged 25-64 participating in education and training" (HCO4)". The variable is strongly reflected by one indicator in the 2010 model - "percentage of population aged 15-64 having completed tertiary education" (HC01). Two indicators "early leavers from education and training, percentage of population aged 18-24" (HCO5) and "graduates in tertiary education per 1000 of population aged 20-29" (HC06) do not manifest any correlation with the variable in 2010 but are weakly correlated in 2014. The results show that education and training were the most important factors of 
human capital in EU countries in 2010-2014. An interesting result is also the significant impact of health indicators on $H C$ variable $(H C 17$ - moderate correlation and $H C 19$ - weak correlation). In many studies, such indicators do not show a correlation with human capital.

Indicators of latent variable $S G$ have better statistical properties in the 2014 model. In the 2014 model two indicators are very strongly, three strongly, three moderately and three weakly correlated with $S G$ variable. Meanwhile in the 2010 model three indicators are not correlated with $S G$ variable. The results of both estimations show that in the EU countries in 2010-2014 the level of knowledge was more important factor of smart growth than the level of innovation.

The estimates of the internal relationships parameters are illustrated with an equations (2) and (3). The standard deviations, calculated with the use of the Tukey's test, are given in brackets.

$$
\begin{array}{rr}
\hat{S} G_{2010}=0.8774 H C_{2010}+ & 0.0109 \\
(0.0343) & (0.2499) \\
\mathrm{R}^{2}=0.77 \quad \mathrm{~S}-\mathrm{G}= & 0.60 \\
& \\
\hat{S} G_{2014}=0.9009 H C_{2014}+ & 0.1763 \\
& (0.0260) \\
\mathrm{R}^{2}= & 0.81 \quad \mathrm{~S}-\mathrm{G}=0.61
\end{array}
$$

The structural parameters for the latent variable $H C$ are statistically significant (" 2 s" rule). The value of the determination coefficient $\mathrm{R}^{2}$ is high $(0.77$ in 2010 and 0.81 in 2014) and justifies the conclusion that the independent variable $H C$ determines the variability of the dependent variable $S G$. The general value of the Stone-Geisser test is positive (0.60 in 2010 and 0.61 in 2014), which suggests a high predictive relevance of the model.

The results of the internal model estimation reveal a significant, positive relationship between human capital and the level of smart growth in the studied group of countries in 2010 as well as in 2014. Countries which had higher stock of human capital, had also higher level of smart growth. This results are consisted with expectation. There is no reason to reject hypothesis that was formulated at the beginning of the paper.

The employment of the PLS method for the estimation of the model's parameters makes it possible to calculate estimates of the values of latent variables (weighted sums of indicators). These values were then taken as the values of the synthetic measure, and on that basis, rankings of the examined countries were constructed according to their levels of human capital (latent variable $H C$ ) and smart growth (latent variable $S G$ ). The results of rankings are presented in Table 4. 
Table 4. Rankings of EU countries according to levels of human capital and smart growth

\begin{tabular}{|c|c|c|c|c|}
\hline \multirow[t]{2}{*}{ Country } & \multicolumn{2}{|c|}{2010} & \multicolumn{2}{|c|}{2014} \\
\hline & $H C$ & $S G$ & $H C$ & $S G$ \\
\hline Austria & 12 & 6 & 10 & 6 \\
\hline Belgium & 10 & 10 & 12 & 11 \\
\hline Bulgaria & 25 & 26 & 25 & 25 \\
\hline Croatia & 28 & 20 & 24 & 23 \\
\hline Cyprus & 13 & 24 & 13 & 27 \\
\hline Czech Republic & 16 & 16 & 15 & 14 \\
\hline Denmark & 1 & 3 & 1 & 3 \\
\hline Estonia & 14 & 14 & 16 & 18 \\
\hline Finland & 2 & 1 & 3 & 2 \\
\hline France & 15 & 11 & 7 & 9 \\
\hline Germany & 11 & 8 & 14 & 5 \\
\hline Greece & 19 & 23 & 19 & 22 \\
\hline Hungary & 26 & 21 & 27 & 21 \\
\hline Ireland & 6 & 5 & 6 & 7 \\
\hline Italy & 20 & 17 & 22 & 16 \\
\hline Latvia & 24 & 27 & 26 & 26 \\
\hline Lithuania & 18 & 22 & 18 & 17 \\
\hline Luxemburg & 9 & 12 & 8 & 12 \\
\hline Malta & 22 & 19 & 21 & 20 \\
\hline Netherlands & 5 & 4 & 5 & 4 \\
\hline Poland & 21 & 25 & 23 & 24 \\
\hline Portugal & 23 & 13 & 20 & 13 \\
\hline Romania & 27 & 28 & 28 & 28 \\
\hline Slovakia & 17 & 18 & 17 & 19 \\
\hline Slovenia & 7 & 9 & 9 & 8 \\
\hline Spain & 8 & 15 & 11 & 15 \\
\hline Sweden & 3 & 2 & 2 & 1 \\
\hline United Kingdom & 4 & 7 & 4 & 10 \\
\hline
\end{tabular}

When comparing the rankings obtained on the basis of 2010 data with those - on the basis of 2014 data, one notices relatively small changes in the ordering of the countries in terms of human capita as well as in terms of the level of smart growth. Only France moved up spectacularly in the $H C$ rankings (15th in 2010, 7th in 2014). In $S G$ rankings Lithuania moved up from 28th position to 24 th position and Estonia recorded drops from 14 th position to 18 th position. 
The next step consisted in dividing the countries into typological groups. The boundaries of the groups were established with the use of the arithmetical mean values and standard deviation of the synthetic variable $z_{i}$ (equaling 0 and 1 for each of the latent variables, respectively). The ranges assumed the following forms:

- group I (very high level of latent variable): $z_{i} \geq 1$,

- group II (high level of latent variable): $0<z_{\mathrm{i}} \leq 1$,

- group III (low level of latent variable): $-1<z_{\mathrm{i}} \leq 0$,

- group IV (very low level of latent variable): $z_{\mathrm{i}} \leq-1$.

In 2010, the following countries boasted very high stocks of human capital: Denmark, Finland, Sweden, United Kingdom and Netherlands. Nine countries were classified in the group with a high stock of human capital: Ireland, Slovenia, Spain, Luxemburg, Belgium, Germany, Austria, Cyprus and Estonia. The group with medium and low stocks of human capital comprised nine countries: France, Czech Republic, Slovakia, Lithuania, Greece, Italy, Poland, Malta and Portugal. Very low stocks of human capital were recorded in five countries: Latvia, Bulgaria, Hungary, Romania and Croatia. In 2014 the first and the fourth groups did not change. In the second and the third groups changes concerned France and Estonia. France moved from third to second group, while Estonia moved from second to third group.

Three countries made up the group with a very high level of smart growth in 2010: Finland, Sweden and Luxemburg. The group of countries with a high level of smart growth included: Netherlands, Ireland, Austria, United Kingdom, Germany, Slovenia, Belgium, France, Luxembourg, Portugal and Estonia. The third group of medium- and low smart growth economies was comprised of Spain, Czech Republic, Italy, Slovakia, Malta, Croatia, Hungary, Lithuania and Greece. Very low levels of smart growth were recorded in: Cyprus, Poland, Bulgaria, Latvia, and Romania. In 2014, there were changes in each group. The first group consisted of: Denmark, Sweden, Finland, Netherlands, while the second one of: Ireland, France, Luxemburg, Slovenia, Austria, Belgium, Germany, Portugal. The third group included the following countries: Spain, Czech Republic, Estonia, Slovakia, Lithuania, Greece, Malta, Italy, Hungary. Five countries: Cyprus, Poland, Croatia, Bulgaria, Latvia, Romania made up the fourth group.

\section{Conclusions}

The studies presented in the paper concerned the analysis of the role of human capital in the processes of smart growth in EU countries in 2010-2014. The soft modelling method used in the research enabled:

- the investigation into the relationships between observed variables and the HC latent variable,

- the investigation into the relationships between observed variables and the SG latent variable,

- the investigation into the influence of human capital on smart growth,

- the estimation of the values of HC synthetic measure as well as SG synthetic measure, 
- the arrangement of countries according to the levels of human capital and smart growth as well as the division of countries into typological groups

In both estimated models indicators had a different strength of impact on the latent variables (from very strong correlation to lack of correlation). Moreover, both estimated models indicated positive influence of human capital on the level of smart growth in the studied group of countries. The highest stock of human capital both in 2010 and in 2014 was characteristic for Denmark, Finland, Sweden, United Kingdom and Netherlands, whereas the lowest one for Latvia, Bulgaria, Hungary, Romania and Croatia. Only two countries Finland, Sweden were classified in the group with very high level of smart growth both in 2010 and in 2014. The lowest level of smart growth were recorded in Cyprus, Poland, Bulgaria, Latvia, Romania.

Human capital is a significant factor of economic growth and smart growth. Therefore, determination of the stock and prospects of human capital development is an important issue today, both in economic theory and business practice. Human capital should be considered as a complex, multifaceted category with various intangible dimensions that are not directly observable and that cannot be measured with precision by a single attribute. The research on human capital and smart growth presented in this paper should be treated as a starting point for further work.

\section{References}

1. Bal-Domańska, B.: Does smart growth enhance economic cohesion? An analysis by the level of research and development activities intensity. Prace Naukowe Uniwersytetu Ekonomicznego we Wrocławiu No. 286, Wrocław (2013).

2. Benhabib, J., Spiegel, M. M.: The role of human capital in economic development: Evidence from aggregate cross-country data. Journal of Monetary Economics 34 (2), $143-$ 173 (1994), DOI: 10.1016/0304-3932(94)90047-7.

3. Bergström, R, Wold, H. (eds.): Fix-Point Estimation in Theory and Practise. Vandenhiecj\&Ruprecht (1983).

4. Chen, D. H. C., Dahlman, C. J.: The Knowledge Economy, the KAM Methodology and World Bank Operations. World Bank Institute, Washington (2005).

5. Ciborowski, R. W., Skrodzka, I.: International technology transfer as innovation factor in EU countries. International Journal of Technological Learning, Innovation and Development 8(4), 399-415 (2016), DOI: 10.1504/IJTLID.2016.10002639.

6. European Commission: Europe 2020. A European strategy for smart, sustainable and inclusive growth, http://ec.europa.eu/eu2020/pdf/COMPLET\%20EN\%20BARROSO $\% 20 \% 20 \% 20007 \% 20-\% 20$ Europe $\% 202020 \% 20-\% 20$ EN\%20version.pdf, last accessed 2017/10/12.

7. European Commission: Innovation Union Scoreboard 2017, http://ec.europa.eu/ DocsRoom/documents/24829, last accessed 2017/10/12.

8. Esposito Vinzi, V., Chin, W.W., Henseler, J., Wand, H. (eds.): Handbook of Partial Least Squares: Concepts, Methods and Applications. Springer-Verlag, Berlin Heidelberg (2010).

9. Jöreskog, K., Wold, H. (eds.): Systems Under Indirect Observation: Causality, Structure, Prediction. North-Holland, Amsterdam (1982).

10. Lomhmöller, J.B.: Latent Variable Path Modeling with Partial Least Squares. SpringerVerlag, Berlin Heidelberg (1989). 
11. Lucas, R. E.: On the Mechanics of Economic Development. Journal of Monetary Economics 22(1), 3-42 (1988), DOI: 10.1016/0304-3932(88)90168-7.

12. Mankiw, N. G., Romer, D., Weil, D. N.: A contribution to the empirics of economic growth. Quarterly Journal of Economics 107 (21), 407-437 (1992), DOI: 10.3386/w3541.

13. Markowska, M., Strahl, D.: European regional space classification regarding smart growth level. Comparative Economic Research. Central and Eastern Europe 15(4), 233-247 (2012), DOI: 10.2478/v10103-012-0038-2.

14. Markowska, M., Strahl, D.: Filary inteligentnego rozwoju a wrażliwość unijnych regionów szczebla NUTS 2 na kryzys ekonomiczny - analiza wielowymiarowa. Taksonomia 26, 118-129 (2016), DOI: 10.15611/pn.2016.426.12.

15. OECD: Technology and Industry Scoreboard 2001 - Towards a knowledge-based economy, http://www.oecd-ilibrary.org/industry-and-services/oecd-science-technologyand-industry-scoreboard-2001_sti_scoreboard-2001-en, last accessed 2017/10/12.

16. Piech, K.: Wiedza i innowacje w rozwoju gospodarczym: w kierunku pomiaru i współczesnej roli państwa. Instytut Wiedzy i Innowacji, Warszawa (2009).

17. Rogowski, J.: Modele miękkie. Teoria i zastosowanie w badaniach ekonomicznych. Wydawnictwo Filii UW w Białymstoku, Białystok (1990).

18. Romer, P. M.: Human capital and growth: Theory and evidence. Carnegie-Rochester Conference Series on Public Policy 32, 251-286 (1989), DOI: 10.1016/01672231(90)90028-J.

19. Skrodzka, I: Kapitał ludzki polskich województw - koncepcja pomiaru. Wydawnictwo Uniwersytetu w Białymstoku, Białystok (2015).

20. Skrodzka, I.: Knowledge-Based Economy in the European Union - cross-country analysis. Statistics in Transition new series 17(2), 281-294 (2016), DOI: 10.21307/stattrans-2016019.

21. Strahl, D.: Klasyfikacja europejskiej przestrzeni regionalnej ze względu na filary inteligentnego rozwoju $\mathrm{z}$ wykorzystaniem referencyjnego systemu granicznego. Prace Naukowe Uniwersytetu Ekonomicznego we Wrocławiu No. 327, Wrocław (2014).

22. Wold, H.: Soft modelling: Intermediate between Traditional Model Building and Data Analysis. Mathematical Statistics 6(1), 333-346 (1980).

23. Wold, H.: Soft modeling: The basic design and some extensions, In: Joreskog K, Wold H (eds) Systems Under Indirect Observation: Causality, Structure, Prediction. Boston Harvard Business School Press (1982). 